ZOOLOGIA 27 (3): 465-471, June, 2010

doi: $10.1590 /$ S1984-46702010000300021

\title{
Description of the immature stages of Leptonema tridens (Insecta: Trichoptera: Hydropsychidae) from southeastern Brazil with notes on its biology
}

\author{
Jorge Luiz Nessimian ${ }^{1,2}$ \& Leandro Lourenço Dumas ${ }^{1}$
}

\author{
${ }^{1}$ Departamento de Zoologia, Instituto de Biologia, Universidade Federal do Rio de Janeiro. Caixa Postal 68044, Cidade \\ Universitária, 21941-971 Rio de Janeiro, Rio de Janeiro, Brazil. E-mail: nessimia@acd.ufrj.br; dumas_bioufrj@yahoo.com.br \\ ${ }^{2}$ Corresponding author.
}

\begin{abstract}
The larva and pupa of Leptonema tridens Mosely, 1933 are described and illustrated. Larvae of L. tridens can be distinguished from other described larvae of Leptonema Guérin, 1843 mainly by the rodlike setae of the labrum and the forecoxa lacking processes, bearing only a row of spiniform setae on its inner surface. The specimens were collected in different localities of the Mantiqueira mountain range, Itatiaia massif, states of Minas Gerais and Rio de Janeiro, southeastern Brazil. Larvae build typical hydropsychid shelters and are found in rapids, attached to rocky substrates. Gut content analysis revealed that larvae are omnivorous-filterers.
\end{abstract}

KEY WORDS. Aquatic insects; Atlantic Forest; caddisflies; mountain streams; Neotropics.

The net-spinning caddisfly Hydropsychidae is one of the largest families in the Trichoptera, with about 1,500 described species worldwide. This family is currently divided into five subfamilies: Arctopsychinae, Macronematinae, Hydropsychinae, Diplectroninae, and Smicrideinae. Only Arctopsychinae is not found in the Neotropics, being widespread in the Holarctic and Oriental regions (Fuint et al. 1999, Holzenthal et al. 2007). Leptonema Guérin, 1843 contains approximately 120 species and is the largest genus of Macronematinae (FuINT et al. 1987, FuINT 2008). This genus is especially diverse in the Neotropical Region, with some species extending into the southwestern USA, and a considerable number of species recorded from Africa and Madagascar (Holzenthal et al. 2007). Funt et al. (1987) revised the whole genus and also considered biogeographic and phylogenetic aspects. Brazil has 27 recorded species (PAPROCKI et al. 2004, Flint 2008, Dumas \& Nessimian 2009).

Larvae of hydropsychids live in running waters and are generally collectors-filterers, although some species are predators of larval black flies (Davies 1981, Merritt \& Cummins 1996). They usually construct a silken filter net at the entrance to their fixed tubular retreat (WIGGINs 1996). The same retreat is adapted for the pupal stage with the enclosure being reinforced with larger pieces of rock and lacking a capture net (WIGgINs 2004).

The knowledge of the taxonomy and biology of immature caddisflies is quite relevant to the study of fluvial ecosystems. Larvae present a high ecological diversity and display a wide range of tolerance to different levels of pollution, which makes them very useful organisms in biological water quality monitoring programs (RESH 1995). Among the 2,230 species of caddisflies in the Neotropics (FunT et al. 1999), only about 2\% have been described in their larval stages (Holzenthal 2004). Trichoptera of the family Hydropsychidae are extremely important in the ecology of running waters because of their high density and biomass (WIGGINs 2004). Nevertheless, few species have their immature stages associated with the corresponding male adults. Larvae of New world Leptonema species have been described by Müller (1921), Flint $(1964,1968)$, Flint \& Wallace (1980), and Botosaneanu (1994), whereas larvae of Old World species have been described by Marlier $(1961,1962)$ and SCOTT (1983).

Herein we describe and figure the larva and pupa of Leptonema tridens Mosely, 1933 from the Mantiqueira mountain range, Itatiaia massif, states of Minas Gerais and Rio de Janeiro, southeastern Brazil. Some notes on the biology of the species are provided.

\section{MATERIAL AND METHODS}

The specimens were collected by hand and with Surber nets from fast flow zones of rivers and streams in the Mantiqueira mountain range, southeastern Brazil. Larvae and pupae were attached to the rock substrate in moderately to fast flowing water. The larval and pupal morphological terminology follows Flint \& Wallace (1980) and Wiggins $(1996,2004)$. The immature forms were associated with adults using the metamorphotype method, which relies on the collection of a pharate male within the pupal case or shelter (Milne 1938, Wiggins 1996). A total of five pharate males, 11 pupae, and 10 larvae were used in the measurements. The illustrations were made under a stereomicroscope Zeiss SV6 equipped with a cam- 
era lucida. All specimens were deposited in the Coleção Entomológica Prof. José Alfredo Pinheiro Dutra (DZRJ), at Departamento de Zoologia, Instituto de Biologia, Universidade Federal do Rio de Janeiro, Rio de Janeiro.

\section{TAXONOMY}

\section{Leptonema tridens Mosely, 1933}

Mosely, 1933: 17 [Type locality: Brazil, Paraná; BMNH; male]; Flint, McAlpine \& Ross, 1987: 46 [male, distribution].

Description. Larva (Figs 1-13): total length 31.0-40.0 mm; maximum head width $4.5 \mathrm{~mm}$; maximum thorax width 5.5 $\mathrm{mm}$. General color brown; head brown, immaculate, posteriorly stramineous, with clypeus and area surrounding stemmata yellowish-brown; thoracic sclerites brown with fuscous lateral spots, posterolateral margins of pro- and mesonotum black (Fig. 1). Head (Figs 2-6): slightly longer than wide. Anterior third of dorsal surface and area behind stemmata regularly covered with short, erect, truncate, rodlike setae. Frontoclypeus glabrous, with anterior margin straight (Fig. 2). Labrum transverse, covered with rodlike setae, except at median line; anterior margin with short, fine, golden setae; anterolateral angles with one dark seta and a tuft of golden setae (Fig. 3). Mandibles assymmetrical; left mandible bearing a mesal tuft of fine setae, with one double basal, three mesal and two additional apicodorsal teeth; right mandible without tuft of setae, with one double basal, three mesal (two of them partially fused) and one additional apicodorsal teeth; outer margin of both mandibles with short, dark setae (Fig. 4). Submentum trapezoidal, bearing about 6-7 setae anterolaterally; outer margin concave (Fig. 5). Transverse stridulatory file ridges on ventrolateral area of head elliptical, with more than 40 ridges. Anterior ventral apotome triangular, not divided (Fig. 6). Thorax (Figs 7-11): pronotum with small laterodorsal spots on posterior third; anterior margin slightly concave, with short setae (Fig. 7). Prosternum trapezoidal, transversely depressed, with a lightly sclerotized, rectangular posteromesal lobe (Fig. 8). Mesoand metanotum each with anterior margin almost straight, bearing a row of short setae; posterior margin with scattered, short dark setae; small laterodorsal spots present (Fig. 7). Mesoand metasternum membranous, covered by fine, dark setae; mesosternum with one pair of gills near base of coxae; metasternum with two pairs of gills, one near median line of segment and one near base of coxae. Fore trochantin setose, triangular, acute apically, almost half length of fore coxa (Fig. 9). Fore leg short; inner surface of coxa with a row of stout spiniform setae; ventral surface of femur and trochanter with brush of golden setae; femur broad, with an obtuse protuberance on basal third (Figs 9 and 10). Mid- and hind legs virtually identical in shape and structure; apical margin of coxa densely covered by long, dark setae; ventral surface of femur and trochanter covered with golden setae (Fig. 11). Tarsal claw of fore leg falci- form, obtuse apically, with basal, broad accessory seta, subequal in length to the claw; mid- and hind claws very broad, with basal acessory setae (lacking in a few specimens) (Figs 10 and 11). Abdomen (Figs 12 and 13): integument densely covered by blunt, slightly broadened, elongate, black setae. Lateral fringe of setae absent; one long dark seta laterally on each of segments I-VII, above base of gills. Sternum IX with two slightly sclerotized areas covered by golden setae; posterior margin with a row of long, dark setae. Ventral gills on segments I-VIII; segments I and VIII with two pairs; segments II-VII with three pairs; gills decreasing in length up to abdominal posterior end. Sternum VIII with a small oval pair of sclerites covered by dark long setae. Sternum IX with a large pair of lightly sclerotized sclerites covered by short golden setae; posterior margin with row of long dark setae (Fig. 12). Some individuals with four everted anal papilae. Anal prolegs long, covered by short dark setae; inner surface with fringe of pale slender setae; tuft of long apicodorsal setae present; lateral sclerites present basally; anal claw short, sharply angled ventrad, without accessory teeth, with a basal tuft of short dark setae (Fig. 13).

Pupa (Figs 14-18): total lenght: female 12.5-14.0 mm, male 10.0-12.0 mm. Head (Figs 14 and 15): mandibles falciform, flattened dorsoventrally, curved inward, tapering to apex, assymetrical; inner margin serrate on apical third, mesal third bearing three acute teeth in right mandible and four in left mandible; outer margin basally with a cluster of dark setae (Fig. 14). Labrum swollen, trapezoidal; anterior margin slightly depressed mesally, bearing a tuft of approximately 20 setae; basilateral lobes with a group of 5-6 setae; anterolateral margins rounded, bearing approximately 15 setae. Front of face with a group of shorter setae anterolaterally, two groups of long, dark, hooked setae medially, and a few scattered setae laterally above base of mouth parts, and behind and in front of eyes. Vertex with two groups of three long dark setae on each side. Basal segment of antennae with a group of 7-8 setae (Fig. 15). Thorax: mesonotum with a tuft of dark setae anterolaterally; two pairs of setae mesally, one anterior and one posterior. Mesoand metanota each with a pair of submesal setae posteriorly. Mesothoracic legs with a hair fringe on both sides of tarsus; tarsus flattened. Metathoracic legs with coxae bearing a comb of setae. Wing pads reaching posterior margin of abdominal segment IV. Abdomen (Figs 16 and 18): segments III-VII with lateral, membranous acute lobes; segment III with a short single lobe; segments IV-VII with two lobes (Fig. 16). Lateral fringe absent. Gills ventrally on segments II-VII, with two branches, less developed on segment VII. Segment I with dorsal transverse striae. Hook plates anteriorly on segments II-VIII, plates II-IV with many minute teeth, plates V-VIII with 3-4 teeth on distinctly elevated lobes; posterior plates on segment III ovoid lengthwise (Fig. 17). Segments I-IX with surface sparsely covered by dark setae; segment IV more densely setose; segments I-VII with few dorsolateral setae. Apical processes upturned with a group of basilateral dark setae and scattered lateral short se- 


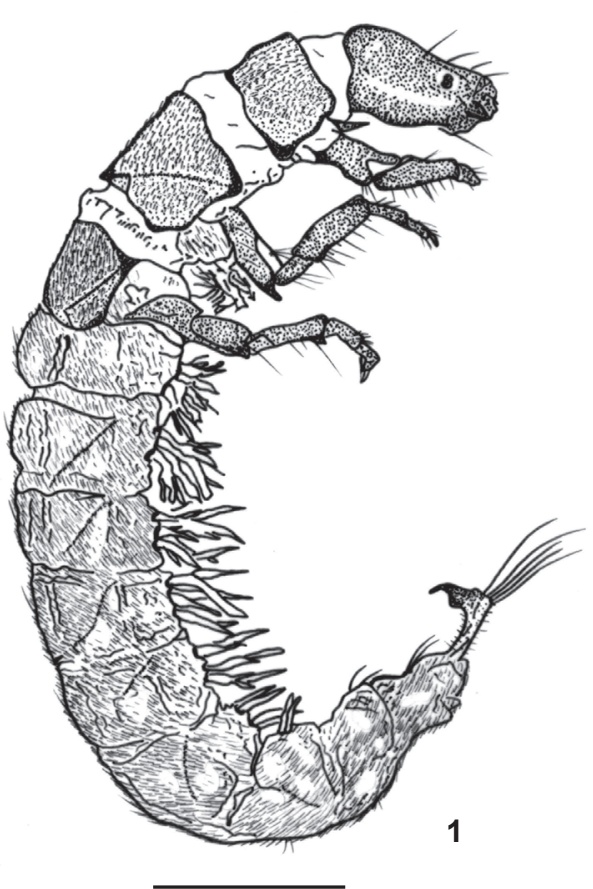

$5.0 \mathrm{~mm}$

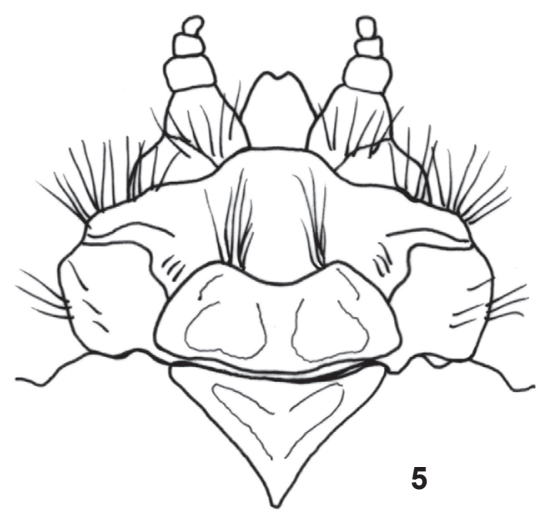

$1.0 \mathrm{~mm}$
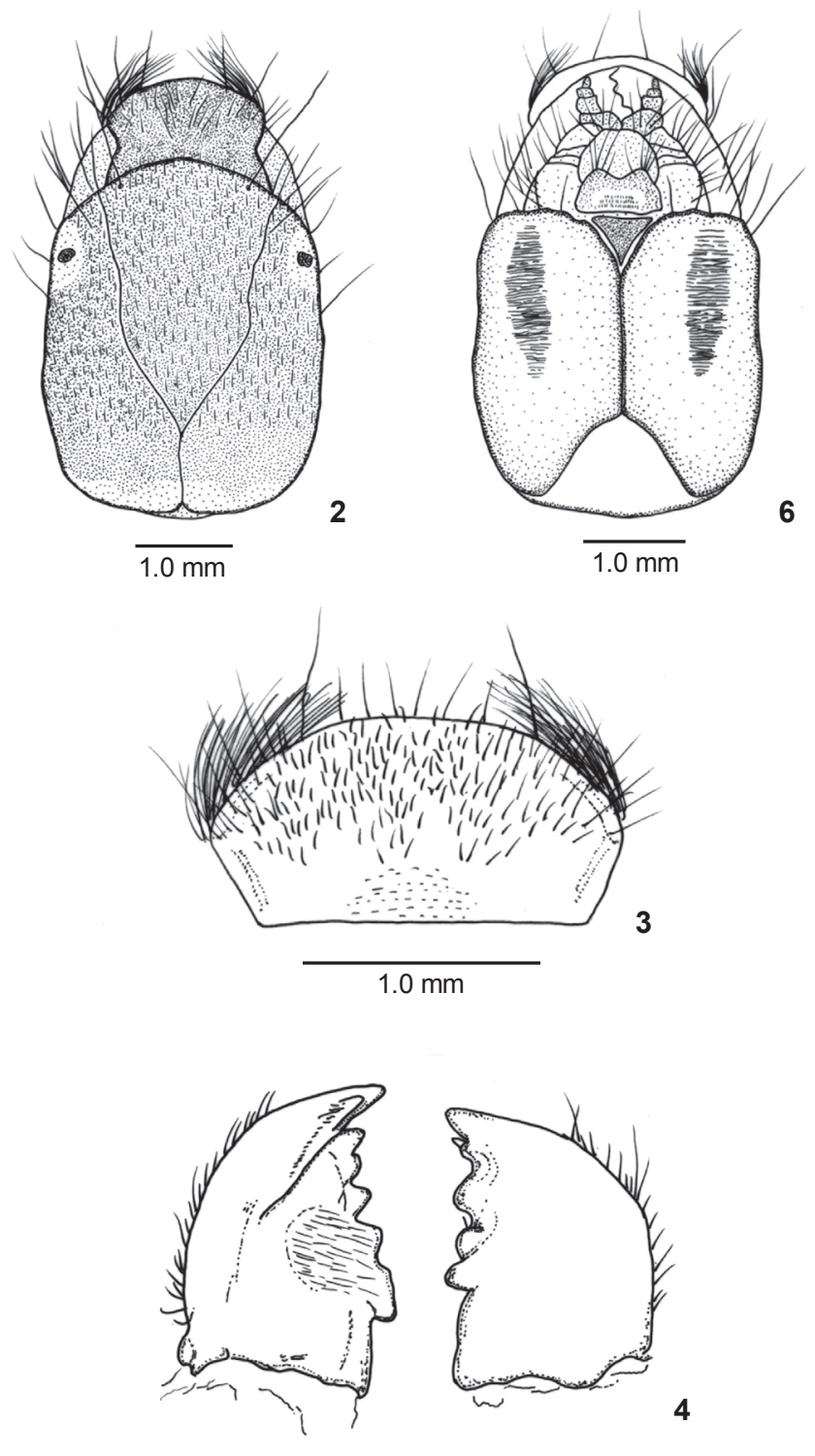

$1.0 \mathrm{~mm}$

Figures 1-6. Leptonema tridens, larva: (1) larva, lateral view; (2) head, dorsal view; (3) labrum, dorsal view; (4) mandibles, dorsal view; (5) maxillolabium, ventral view; (6) head, ventral view.

tae; each process with two groups of long, golden hooked setae near apex and minute spiniform setae ventrally on apical third (Fig. 18). Pupal shelter: length $30.0 \mathrm{~mm}$, width $20.0 \mathrm{~mm}$. Ovoid, ventral area attached to substrate, closed by silk. Surface evenly formed of sand grains and gravel, sometimes with a small stone laterally attached. Each end with small respiratory openings made with silk between particles.

Taxonomic summary. Larvae: Brazil: Minas Gerais: Itamonte municipality (Vargem Grande, Rio Aiuruoca, $\left.21^{\circ} 18^{\prime} 31.6^{\prime \prime} \mathrm{S} 44^{\circ} 41^{\prime} 53.3^{\prime \prime} \mathrm{W}, 1450 \mathrm{~m}\right), 17$ larvae, 15.ix.1996, J.L. Nessimian leg., DZRJ-2266; Itamonte municipality (Rio Aiuruoca, $\left.22^{\circ} 20^{\prime} 56.9^{\prime \prime} \mathrm{S} 44^{\circ} 41^{\prime} 37.9^{\prime \prime} \mathrm{W}, 1860 \mathrm{~m}\right), 13$ larvae, 18.x.1997, J.L. Nessimian leg., DZRJ-2267; same data, 18 larvae, DZRJ-2268; same locality, 14 larvae, 12.ix.1998, J.L. Nessimian leg., DZRJ-2269; same data, 1 larva, DZRJ-2270; same locality, 3 larvae, 02.x.1999, A.A. Huamantinco leg., DZRJ-2271; same data, 1 larva, DZRJ-2272; same locality, 2 larvae, 07.ix.2000, A.A. Huamantinco leg., DZRJ-2273; same locality, 1 


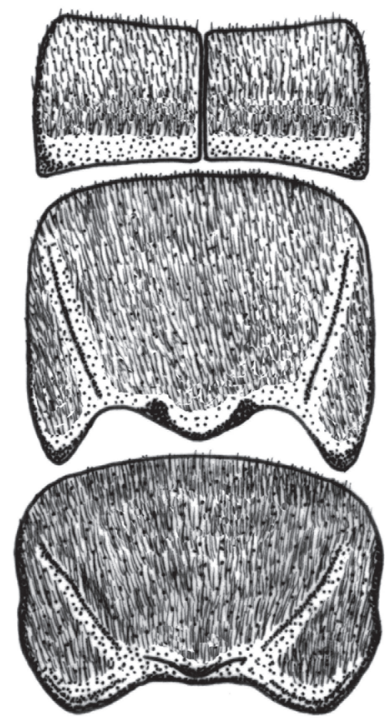

7

$2.5 \mathrm{~mm}$

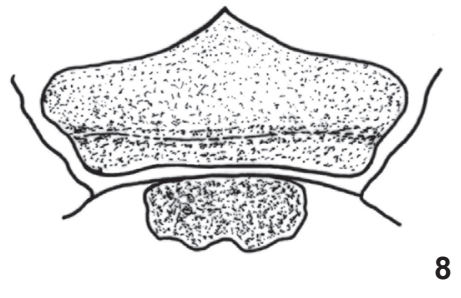

8

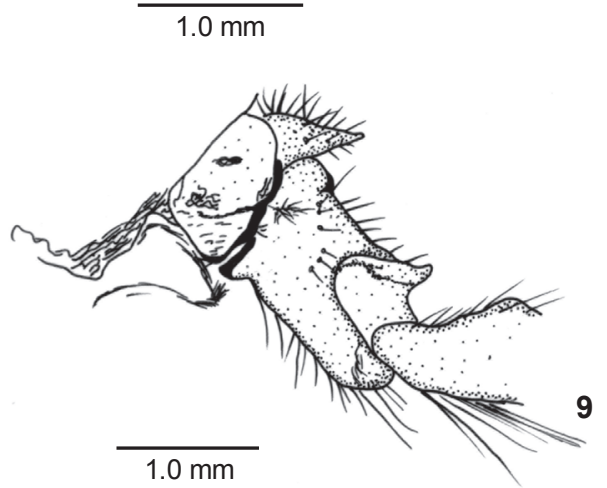

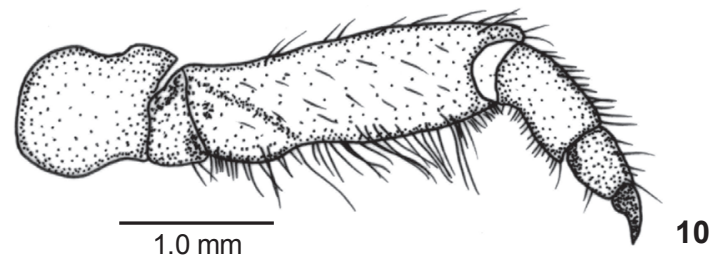
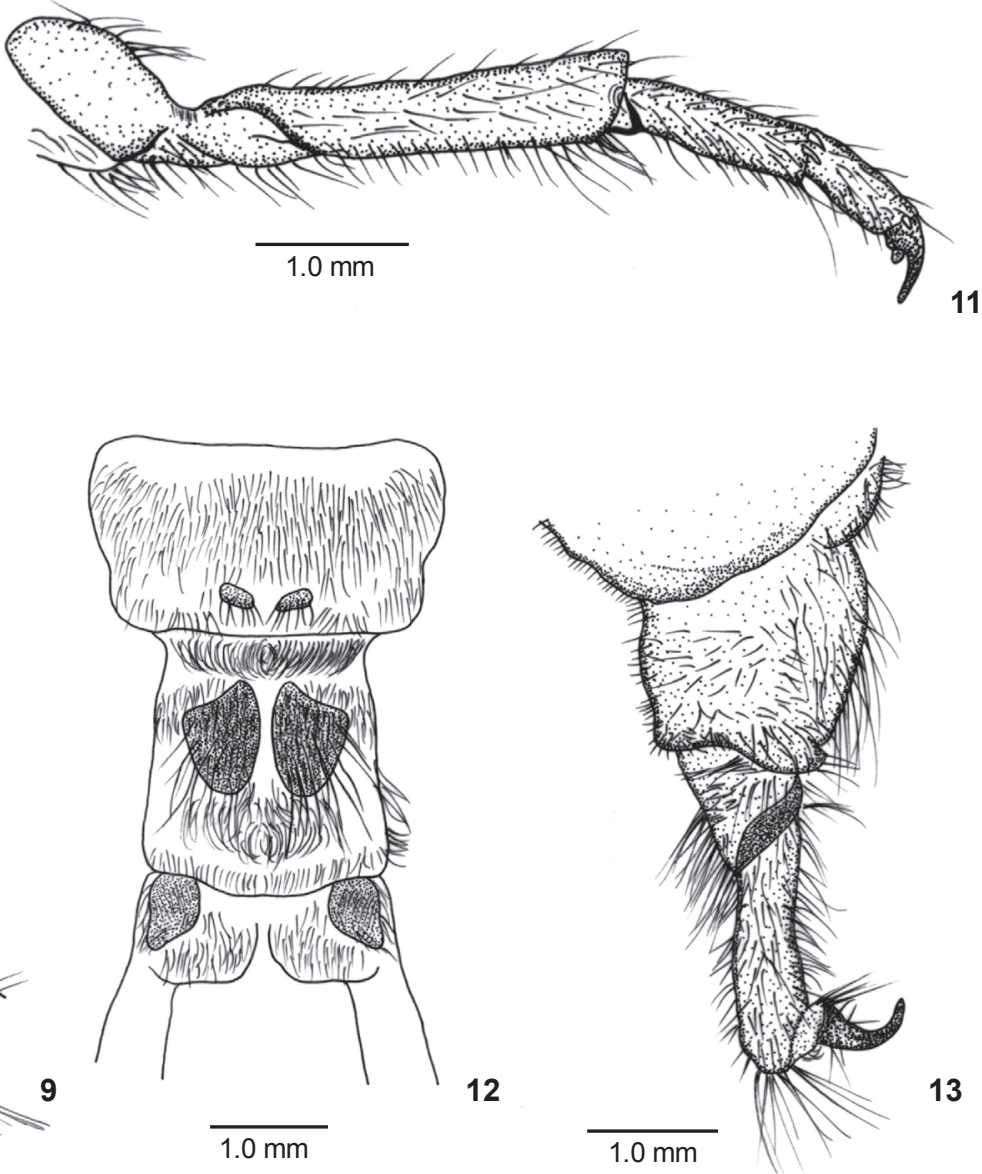

Figures 7-13. Leptonema tridens, larva: (7) thoracic nota, dorsal view; (8) prosternum, ventral view; (9) propleura and coxa, lateral view; (10) foreleg, lateral view; (11) hindleg, lateral view; (12) eighth and ninth sterna, ventral view; (13) anal proleg, lateral view.

larva, 08.ix.2000, J.L. Nessimian leg., DZRJ-2274; same locality, 5 larvae, 05.iv.2001, A.A. Huamantinco leg., DZRJ-2275; same data, 9 larvae, DZRJ-2276; same locality, 17 larvae, 13.x.2001, A.A. Huamantinco leg., DZRJ-2277; same locality, 22 larvae, 18.iii.2004, V.P. Alecrim leg., DZRJ-2278; same locality, 10 larvae, 08.iv.2005, L.L. Dumas and J.L. Nessimian leg., DZRJ-2279; same locality, 7 larvae, 20.xi.2008, L.L. Dumas leg., DZRJ-2280; same locality, 21 larvae, 21.xi.2008, L.L. Dumas and A.L. Pimenta leg., DZRJ-2281; same data, 6 larvae, DZRJ-2282; same data, 1 larva, DZRJ-2283; same data, 1 larva, DZRJ-2284; same data, 1 larva, DZRJ-2285; Bocaina de Minas municipality (Córrego do Morro Cavado, 22¹8'47.2"S 44³6'48.8”W, 1240 m), 5 larvae, 13.x.2000, A.A. Huamantinco leg., DZRJ-2286; same data, 10 larvae, DZRJ-2287; same locality, 13 larvae, 

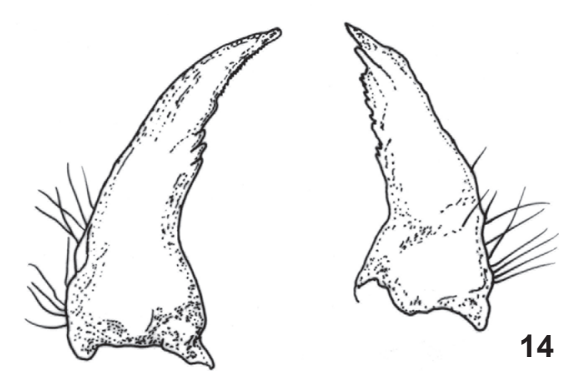

$1.0 \mathrm{~mm}$

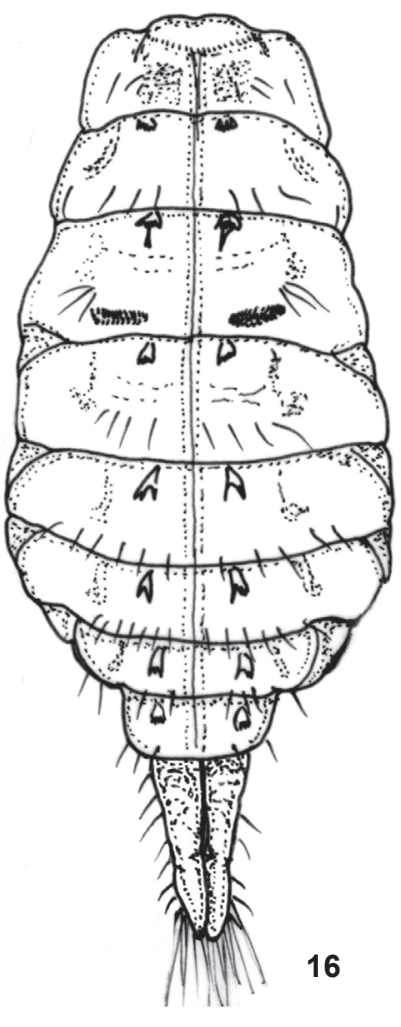

$5.0 \mathrm{~mm}$

14

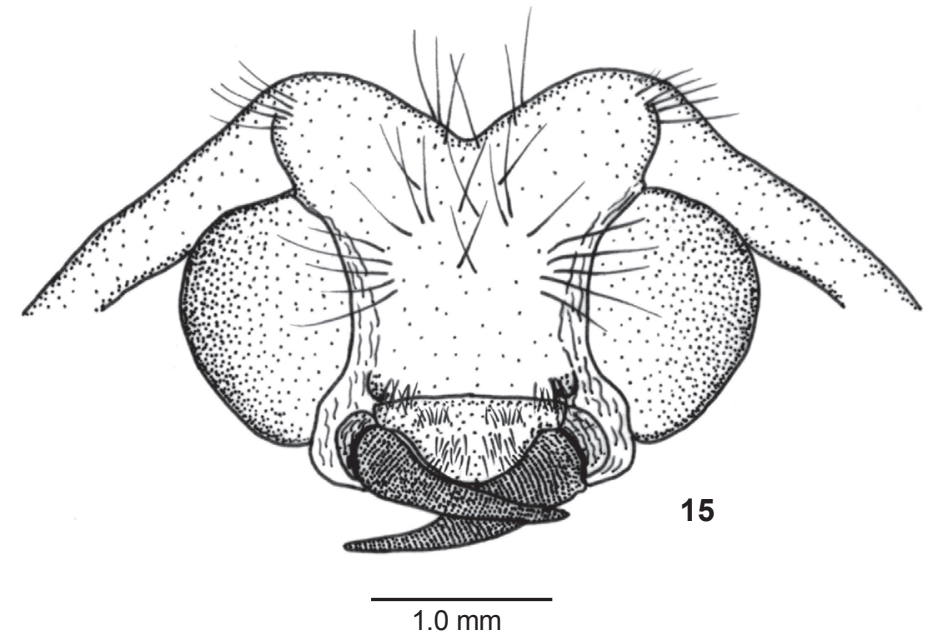

IIA

IIIA
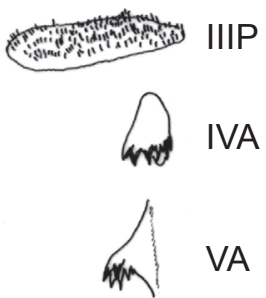

An VIA

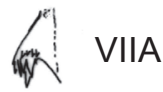

缘 VIIIA

17

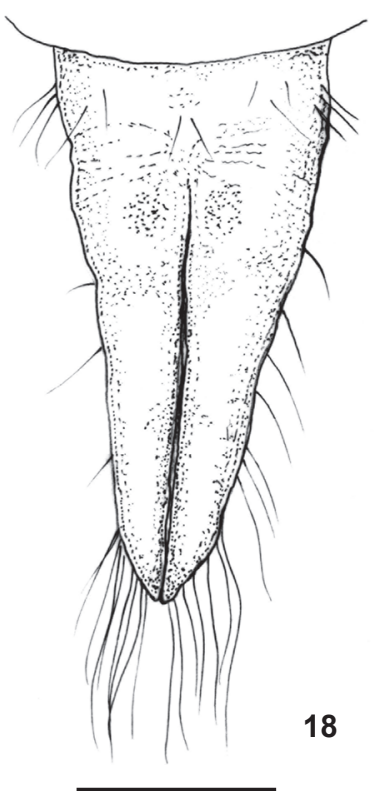

$1.0 \mathrm{~mm}$

Figures 14-18. Leptonema tridens, pupa: (14) mandibles, dorsal view; (15) head, frontal view; (16) abdomen, dorsal view; (17) hook plates, dorsal view; (18) apex of abdomen, dorsal view.

06.iv.2001, A.A. Huamantinco leg., DZRJ-2288; Rio de Janeiro: Itatiaia municipality (Rio Marimbondo, 22 $21^{\prime} 42.2^{\prime \prime} \mathrm{S} 44^{\circ} 35^{\prime}$ 13.9"W, 950 m), 1 larva, 14.x.2000, A.A. Huamantinco leg., DZRJ-2289; same locality, 5 larvae, 07.iv.2001, A.A. Huamantinco leg., DZRJ-2290; Itatiaia municipality (Maromba, Rio Preto tributary, $\left.22^{\circ} 19^{\prime} 67.9^{\prime \prime} \mathrm{S} 44^{\circ} 36^{\prime} 56.8^{\prime \prime} \mathrm{W}, 1148 \mathrm{~m}\right), 8$ larvae, 15.X.2000, A.A. Huamantinco leg., DZRJ-2291; same locality, 32 larvae, 08.iv.2001, A.A. Huamantinco leg., DZRJ-2292; Itatiaia municipality (Vale das Cruzes, Rio das Cruzes tributary, $\left.22^{\circ} 20^{\prime} 25.2^{\prime \prime} \mathrm{S} 44^{\circ} 25^{\prime} 41.9^{\prime \prime} \mathrm{W}, 1316 \mathrm{~m}\right), 1$ larva, 27.ix.2007, L.L. Dumas, A.P.M. Santos, G.A. Jardim and J.L. Nessimian leg., DZRJ2293; Itatiaia municipality (Parque Nacional do Itatiaia, Córrego

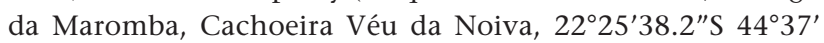
05.8”W, 1032 m), 8 larvae, 16.iv.2007, L.L. Dumas, A.P.M. Santos, N. Ferreira Jr. and J.L. Nessimian leg., DZRJ-2294. Pupae: Brazil: Minas Gerais: Itamonte municipality (Rio Aiuruoca, $\left.22^{\circ} 20^{\prime} 56.9^{\prime \prime} \mathrm{S} 44^{\circ} 41^{\prime} 37.9^{\prime \prime} \mathrm{W}, 1860 \mathrm{~m}\right), 1$ pupa, 18.v.1998, J.L. Nessimian leg., DZRJ-2295; same data, 1 pupa, DZRJ-2296; same 
data, 1 pharate male, DZRJ-2297; same data, 1 pharate male, DZRJ-2298; same data, 1 pharate male, DZRJ-2299; same data, 5 empty shelters, DZRJ-2316; same data, 4 empty shelters, DZRJ2317; same locality, 1 pharate female, 12.xi.1998, J.L. Nessimian leg., DZRJ-2300; same locality, 1 pupa, 08.ix.2000, A.A. Huamantinco leg., DZRJ-2301; same data, 1 exuvia, DZRJ-2302; same locality, 1 pupa, 21.xi.2008, L.L. Dumas and A.L. Pimenta leg., DZRJ-2303; same data, 1 pharate male, DZRJ-2304; same data, 1 pharate male, DZRJ-2305; same data, 1 pharate male, DZRJ-2306; same data, 1 pharate female, DZRJ-2307; same data, 1 pharate female, DZRJ-2308; same data, 5 empty shelters, DZRJ2318; same data, 5 empty shelters, DZRJ-2319; same data, 5 empty shelters, DZRJ-2320; Bocaina de Minas municipality

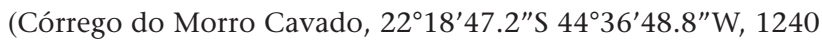
m), 1 pupa, 10.ix.2000, A.A. Huamantinco leg., DZRJ-2309; same data, 1 pupa, DZRJ-2310; same data, 1 pupa, DZRJ-2311; same data, 1 pupa, DZRJ-2312; same data, 1 pupa, DZRJ-2313; same data, 1 pupa, DZRJ-2314; same data, 1 pupa, DZRJ-2315.

Remarks. A few Leptonema species have their larvae described and accurately associated to adults. On the basis of published descriptions, the larva of Leptonema tridens is very similar to that of L. columbianum Ulmer, 1905. It can be distinguished from L. columbianum and L. insulanum Banks, 1924 by the rodlike setae of the labrum (except at median line, which is glabrous). In these species the labrum is covered by many pale fine setae, lacking a glabrous area (FLINT 1964, FLINT \& WaLLACE 1980). Leptonema tridens can also be distinguished from L. columbianum by having a fore coxa without a forked digitate process on its anterior margin (FLINT \& W ALLACE 1980). In the description of the probable larva of L. poeyi (Banks, 1938) the forecoxa bears two short spines on a conical protuberance and two or three longer spines on the ridge proximally to this protuberance (BotosaneANU 1994). Leptonema albovirens (Walker, 1852) and L. archboldi Flint, 1968 have an anteroapical process on the forecoxa (FLINT 1968). Leptonema tridens lacks an anteroapical process and spines on its forecoxa, having only a row of spiniform setae on the inner face of forecoxa. The larva of $L$. tridens is also similar to that of $L$. natalense Mosely, 1933, from South Africa, but it can be distinguished by the absence of a thumb-like process on distal margin of the forecoxa. The pupa of $L$. tridens is very similar to those $L$. columbianum and L. natalense, the only two described pupae of Leptonema. However, based on the descriptions, there are more similarities with the African species, especially in the mandibular dentation. In L. columbianum, the inner margin of mandibles is regularly serrate, whereas in $L$. tridens and L. natalense there are one apical and three lateral teeth on the right mandible and one apical and four lateral teeth on the left mandible. The distribution of anterior hook plates differs in L. columbianum (segments III-VIII) from L. tridens and L. natalense (segments II-VIII).

Biology and habitat. The specimens were found in small and medium rivers in the Mantiqueira mountain range, Itatiaia massif, in southeastern Brazil at altitudes between $950 \mathrm{~m}$ and $1,860 \mathrm{~m}$ a.s.l. The streams have clean and cold water. The ma- jority of larvae and pupae were collected from a third order section river (Rio Aiuruoca), in the municipality of Itamonte, Minas Gerais state. The average annual temperature at this site is about $18^{\circ} \mathrm{C}$, with average minimum temperature below $13^{\circ} \mathrm{C}$ in the winter (May-September) and average maximum temperature $21^{\circ} \mathrm{C}$ in the summer (November-March) (Viola et al. 2009). The larvae were found under rocks in rapid current zones. They construct a typical hydropsychid fixed tubular retreat with a silken filter net at the entrance, in which larvae capture small food items. Gut content analysis indicated that larvae are omnivorous-filterers. The predominant items were vegetal fragments (plant fibers), animal parts (setae, peaces of cuticle, heads, legs, and claws of insects), filamentous algae (Chlorophyceae), fungi (hyphae and conidiae), and detritus. The pupae were found abundantly in more slowly flowing water, with shelters firmly attached to rocks. Based on collecting data of the studied material, L. tridens has at least two generations per year.

Distribution. This species is well distributed in Southeastern and Southern Brazil, being recorded from four Brazilian states: Minas Gerais, Rio de Janeiro, São Paulo, and Paraná. It was also recorded from Paraguay (Italyaia), however the locality where the species was encountered is quite dubious. FLINT et al. (1987) suggested that this locality is probably a misunderstanding of the original handwritten label made by N. Banks. It may be caused by the visual similarity of the word to Itatiaya (now Itatiaia), a municipality of Rio de Janeiro state (Brazil), where L. tridens is commonly found.

\section{ACKNOWLEDGEMENTS}

We thank members of Laboratório de Entomologia (UFRJ) for aid in collecting specimens and two anonymous referees, who improved the manuscript. The Instituto Chico Mendes de Conservação da Biodiversidade (ICMBio) and Parque Nacional do Itatiaia are thanked for issuing collecting permits (14591-2). This study was partially funded by CNPq, FAPERJ, and CAPES.

\section{LITERATURE CITED}

Botosaneanu, L. 1994. A study of the larvae of caddisflies (Trichoptera) from Cuba. Tropical Zoology 7: 451-475.

DAVIES, D.M. 1981. Predators upon black flies. p. 139-158. In: M. LAIRD (Ed.). Black Flies - The Future for Biological Methods in Integrated Control. New York, Academic Press, XII+339p.

Dumas, L.L. \& J.L. Nessimian. 2009. A new species of Leptonema Guérin (Trichoptera: Hydropsychidae) from southeastern Brazil. Zootaxa 2245: 65-68.

Flint JR, O.S. 1964. The Caddisflies (Trichoptera) of Puerto Rico. University of Puerto Rico, Agricultural Experiment Station, Technical Paper 40: 1-80.

FuINT JR, O.S. 1968. Bredin-Archbold-Smithsonian Biological Survey of Domininca 9. The Trichoptera (Caddisflies) of Lesser Antilles. Proceedings of the United States National Museum 125: 1-86. 
FLINT JR, O.S. 2008. Studies of Neotropical Caddisflies, LXI: New species of Leptonema Guérin (Trichoptera: Hydropsychidae). Proceedings of the Entomological Society of Washington 110: 456-469.

Flint JR, O.S. \& J.B. Wallace. 1980. Studies of Neotropical Caddisflies, XXV: The immature stages of Blepharopus diaphanus and Leptonema columbianum (Trichoptera: Hydropsychidae). Proceedings of the Biological Society of Washington 93: 178-193.

Flint Jr, O.S.; J.F. McAlpine \& H.H. Ross. 1987. A revision of the genus Leptonema Guérin (Trichoptera: Hydropsychidae: Macronematinae). Smithsonian Contributions to Zoology 450: 1-193.

Flint Jr, O.S.; R.W. Holzenthal \& S.C. Harris. 1999. Catalog of the Neotropical Caddisflies (Insecta: Trichoptera). Columbus, Ohio Biological Survey, IV+239p.

Holzenthal, R.W. 2004. Rearing Trichoptera. Nectopsyche, The Neotropical Trichoptera Newsletter 2: 6. Avalaible online at: http://www.entomology.umn.edu/museum/links/ Nectopsyche_2.pdf [Accessed: 25/II/2010].

Holzenthal, R.W.; R.J. Blahnik; A.L. Prather \& K.M. KJer. 2007. Order Trichoptera Kirby, 1813 (Insecta), Caddisflies. In: Z.Q. ZHANG \& W.A. SHEAR (Eds). Linnaeus Tercentenary: Progress in Invertebrate Taxonomy. Zootaxa 1668: 639-698.

Marlier, G. 1961. Hydropsychidae du Kivu. Revue de Zoologie et de Botanique Africaines 63: 158-212.

Marlier, G. 1962. Genera des Trichoptères de l'Afrique. Annales du Musée Royal de l'Afrique Centrale, Série in Octavo, Zoologie, 109: 1-261.

Merritt, R.W. \& K.W. Cummins. 1996. An Introduction to the Aquatic Insects of North America. Dubuque, Kendall/
Hunt, XIII+862p.

MiLne, M.J. 1938. The metamorphotype method in Trichoptera. Journal of the New York Entomological Society 46: 435437.

Mosely, M.E. 1933. A revision of the genus Leptonema (Trichoptera). London, British Museum (Natural History), 69p.

Müller, F. 1921. Briefe und noch nicht veröffentliche Abhandlungen aus dem Nachlass 1854-1897, p. 383-642 In: A. Möller (Ed.). Fritz Müller: Werke, Briefe und Leben 2. Jena, G. Fisher, XVII+667p.

Paprocki, H.; R.W. Holzenthal \& R.J. Blahnik. 2004. Checklist of the Trichoptera (Insecta) of Brazil I. Biota Neotropica 4: 122.

Resh, V.H. 1995. Freshwater macroinvertebrates and rapid assessement procedures for water quality monitoring in developing and newly industrialized countries, p. 167-177. In: W.S. Davies \& T.P. Simon (Eds). Biological Assessement and Criteria. Boca Raton, Lewis Publishers, 415p.

Sсотт, K.M.F. 1983. On the Hydropsychidae (Trichoptera) of southern Africa with keys to African genera of imagos, larvae and pupae and species list. Annals of the Cape Provincial Museums (Natural History) 14: 299-422.

Viola, M.R.; C.R. Mello; F.W. Acerbi Jr \& A.M. Silva. 2009. Modelagem hidrológica na bacia hidrográfica do Rio Aiuruoca, MG. Revista Brasileira de Engenharia Agrícola e Ambiental 13: 581-590.

Wiggins, G.B. 1996. Larvae of the North American Caddisfly Genera (Trichoptera). Toronto, University of Toronto Press, $457 \mathrm{p}$.

Wiggins, G.B. 2004. Caddisflies: The Underwater Architets. Toronto, University of Toronto Press, 292p.

Submitted: 10.III.2010; Accepted: 09.V.2010.

Editorial responsibility: Gabriel L.F. Mejdalani 